\title{
Evaluation of an HSM 208F 14tone HVT-R2 Forwarder Prototype under Conditions of Steep-Terrain Low-Access Forests
}

\author{
Stelian Alexandru Borz, Marina Viorela Marcu, Maria Francesca Cataldo
}

\begin{abstract}
Forwarding technology is well established in use around the world but, at the same time, forwarders are expensive machines that require a good planning to ensure the sustainability of operations. In addition, forwarder market is characterized by a limited pool of customers, therefore innovation attempts may be limited compared to other product development industries. Since the steps towards a full automation of operations are still at their beginning, improvements of forwarder machines may rest in developing and integrating components that could contribute to an increased effectiveness. To respond to such challenges, the Forwarder2020 project developed innovative components that were integrated in a number of forwarder prototypes based on a market pull approach that resulted in a flexible adaptation to customer requirements and work environments. Since one of the typical work environments was that of low access forests, some components (i.e. suspended cabin and transmission system) were engineered to enable faster and safer operations and to economize fuel. As a common validation step is that of bringing field evidence on the performance improvement, this study evaluated the operational speed, productivity and fuel consumption of a forwarder prototype in conditions of a steep-terrain low-access forest. The main findings were very promising as the prototype was able to operate at significantly increased speeds and the fuel savings were evident. For an average forwarding distance of about $1.5 \mathrm{~km}$, net productivity and efficiency rates were estimated at $14.4 \mathrm{~m}^{3} / \mathrm{h}$ and $0.07 \mathrm{~h} / \mathrm{m}^{3}$, respectively. They were related to the availability of wood, and further improvement of such figures is possible by a better organization of tree felling and processing. Operational speed was affected by the condition of skid roads used for forwarding, which were harsh. During the transportation tasks developed on roads typical for forwarding, the machine was able to sustain average speeds estimated at $8 \mathrm{~km} / \mathrm{h}$. As a matter of fact, in such tasks, the dominant operational speed (almost in 100\% of the cases) was higher than $5 \mathrm{~km} / \mathrm{h}$ irrespective of the road condition. Hourly fuel consumption was estimated based on the time in which the engine was working and it amounted to $17.1 \mathrm{l} / \mathrm{h}$. More importantly, by considering the forwarded payload in terms of volume and mass, the unit fuel consumption was estimated to be $1.25 \mathrm{l} / \mathrm{m}^{3}$ and $1.47 l / t$, respectively. These results bring evidence on the performance improvement by modular innovation. In fact, such solutions could answer the challenges related to the sustainability of forest operations in low access forests.
\end{abstract}

Keywords: forwarder, prototype, innovation, effectivenes, module, evaluation

\section{Introduction}

Forwarders are among the most used ground-based machines to extract the wood around the world. They are defined as self-propelled vehicles that are built for use in the transport of trees or their parts into a bunk
(ISO 6814 2009). Their original concept, which is still in use today, dates back to the 60s when the first fullymechanized cut-to-length harvesting system was identified and framed by a Swedish group of researchers (Heinimann 2007), a system that is still considered to be the most technologically advanced in the world 
(Lindroos et al. 2017). While the original system consisted of a harvester and a forwarder, for many reasons that affect the level of mechanization (Vusić et al. 2013), such as the regulatory system, forest type, acceptability of practices and intensity of extractions, in some parts of the world, forwarders are used today in partly mechanized systems that integrate motor-manual felling and processing of trees. A typical example is that of Eastern (Moskalik et al. 2017) and South Eastern (Proto et al. 2017, Stankić et al. 2012) European countries where the forwarder technology is either well established or under the introduction to operation.

The actual concept of forwarders has not been changed significantly compared to the original one, but a significant progress in the forwarding machines development was achieved in key areas such as the ergonomics, environmental impact and automation (Pandur et al. 2009, Stankić et al. 2012). To this direction, even the most advanced actual machines are seen to be partly automated to serve function-specific purposes, and a full automation is still out of reach on a short medium term (Lindroos et al. 2017). This leaves a lot of room for the improvement of machine components to be able to respond to pressing needs of the industry and, in fact, the relation between the two approaches - automation and improvement of components - is rather a synergistic and not a mutually exclusive one. In this regard, one of the key functions that may require improvement is the transportation function because other features, such as the productivity, environmental impact and costs, depend on its performance. The relevant features for this function are both empty and loaded turns, as their co-existence is mandatory to be able to access the wood. There are numerous factors that could affect the performance of the transportation function and, most often, its performance is associated with the forwarding distance (Apafaian et al. 2017, Proto et al. 2018), slope of skid roads (Ghaffaryian et al. 2007) and payload per turn, with the latter being used by some authors to categorize the machines in classes (Stankić et al. 2012). For instance, increment of operational distance was found by most of the studies to be among the critical factors that negatively affect the forwarding productivity. As such, it becomes an important factor, whose effects need to be bridged in many countries, because it can reach quite frequently to more than $1 \mathrm{~km}$ and it is often associated with an increased terrain slope (Borz et al. 2019a). Therefore, for the same machine class in terms of loading capacity, and for the same operational conditions in terms of distance and slope, enabling the transportation function to operate at higher speeds could be crucial to improve the productivity outcomes and to reduce the costs, especially in those conditions in which the access to forest is difficult and the forwarding distances are increased. While overcoming the effects of increased operational distance itself is an important problem to be approached, recent studies have identified several key performance areas to which modern forest operations, therefore the machines developed and used, need to be aligned to. The latest work in this regard has indicated several key performance areas framed around sustainability (Marchi et al. 2018) that need to be addressed by the science behind their corresponding disciplines (Heinimann 2007), with a great emphasis placed on the capabilities of the systems to deliver high-quality wood, in less time, at less costs and with less environmental burdens, while also balancing the system's capabilities with those of human operators - e.g. limitation of exposure to noise and vibration (Poje et al. 2019) - and of the institutional and practice setup in a given area.

Having in mind the above described, the Forwarder2020 project was framed around the operational requirements and preferences of users by a market pull approach (Borz et al. 2019a) to build innovative machines adapted to specific work environments. The project consortium developed innovative modules to be integrated in forwarders in such a way that enabled the flexibility in their purchasing and adaptation to special requirements of users, by approaching key issues such as the increased efficiency of operations, improved environmental protection and a better decision making. Of these, some modules were developed to increase the forwarding efficiency as a response to the high operational distances that are common in many European countries. Examples of modules developed for such environments are the suspended cabin and, in particular, the innovative transmission system that, together with the cabin, was designed to enable faster operations, contributing therefore to productivity increment and to fuel savings. While these capabilities were tested before releasing the prototypes, with excellent results after the development stage, a challenge was that related to testing the improvements in real operational conditions. In particular, the ability to drive at higher speeds compared to the conventional machines, as well as the effectiveness in fuel saving were the main key performance indicators to be demonstrated in real operations. In this regard, it is quite common to use specific techniques to emphasize the effect of technology development and integration into new machines (Visser and Spinelli 2012), therefore to validate their effectiveness.

The focus of this study was on evaluating the improvements brought by the innovations integrated 
into an HSM 208F 14tons HVT-R2 forwarder prototype in terms of productivity, efficiency, operational speed and fuel saving, as the machine was equipped with an innovative, power-split transmission and a hydraulically suspended cabin. The assumptions were that, in particular, the operations could be sustained at a higher speed and, by doing so, the capability of transmission system to save fuel would be enabled.

\section{Materials and Methods}

\subsection{Field Test Location, Stand and Harvesting System Description}

A forested area characterized by a low road density and accessibility was selected for the field test. It

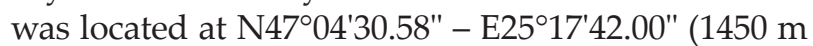
a.s.l.), $25 \mathrm{~km}$ away from Topliţa city, Harghita county, Romania (Fig. 1); the harvested stand was located at about one $\mathrm{km}$ away in straight line from the nearest forest road. The land in the area is characterized by the presence of forests dominated by Norway spruce (Picea abies (Lam.) Link.) that are frequently bordered by alpine pastures. The wood harvested from the area is delivered to both small-sized lumber manufactures as well as to larger wood processing companies. Taking into account the access to the forest stand by a skid- ding road (Fig. 1), the average extraction distance, measured from the center of forest stand to the junction of skidding road to the forest road, was of roughly $1.6 \mathrm{~km}$. The forest stand (Table 1) was harvested by a clear-cut implemented by motor-manual tree felling and processing and the bucked logs were extracted using the forwarder prototype that has been tested for three days, from $26^{\text {th }}$ to $28^{\text {th }}$ of August 2019.

The main descriptive features of the forest, standing stock and system used to harvest the wood are given in Table 1. The mean slope of the terrain in the felling block was of approximately $26 \%$. However, the mean slope of parts of the felling block in which the tests were carried out was much lower, accounting for up to $15 \%$. In total (Table 1), 1105 trees were scheduled for extraction accounting for roughly $1120 \mathrm{~m}^{3}$ overbark (o.b.). About $10 \%$ of that wood was extracted prior the tests by a skidder and a farming tractor and about $20 \%$ was felled, processed and forwarded during the field tests.

Forwarding operations were carried out on an existing skidding road (Fig. 1c,d) that provided access from the forest road to the felling block and that was characterized by an evident heterogeneity in terms of longitudinal slope, surface roughness, surface type and width. Fig. 1d shows four segments that have been conceptually delimited based on the mentioned features:

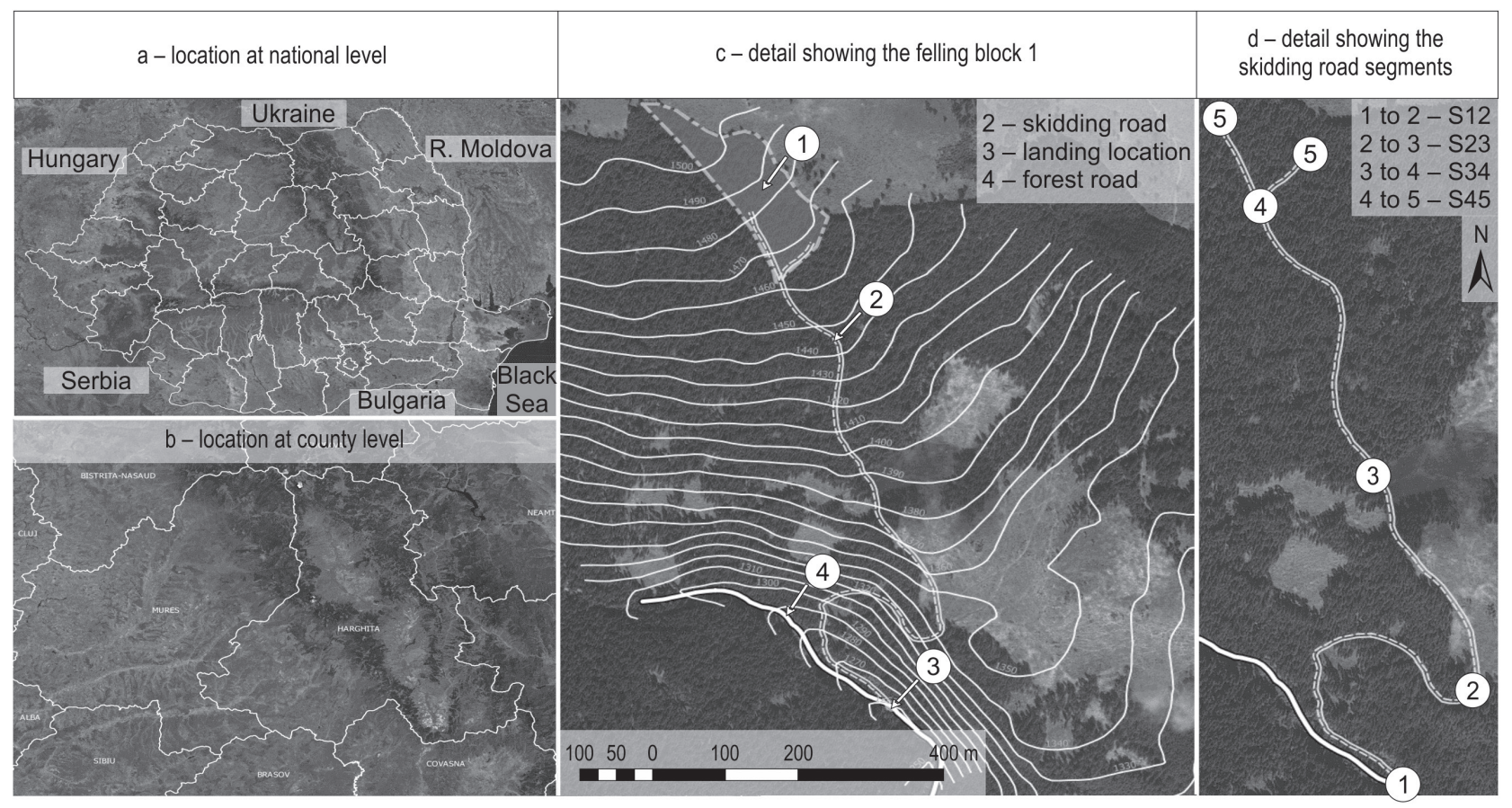

Fig. 1 Location of the field test 
Table 1 Description of forest stand and harvesting system

\begin{tabular}{|l|c|}
\hline \multicolumn{1}{|c|}{ Parameter } & Value \\
\hline Stand composition, \% & 100 Norway spruce $^{\mathrm{a}}$ \\
\hline Age, years & $120^{\mathrm{a}}$ \\
\hline Mean DBH, cm & $40^{\mathrm{a}}$ \\
\hline Mean tree height, $\mathrm{m}$ & $26^{\mathrm{a}}$ \\
\hline Canopy closure, $\%$ & $90^{\mathrm{a}}$ \\
\hline Mean slope, $\%$ & $26^{\mathrm{a}, \mathrm{b}}$ \\
\hline Area, ha & $2.7^{\mathrm{a}}$ \\
\hline Standing stock, $\mathrm{m}^{3}$ over-bark & $1117^{\mathrm{a}}$ \\
\hline Standing stock, $\mathrm{m}^{3}$ under-bark & $1023^{\mathrm{a}}$ \\
\hline Mean volume per tree, $\mathrm{m}^{3}$ over-bark & $1.11^{\mathrm{a}}$ \\
\hline No. of harvestable trees & 1005 \\
\hline Harvesting year & 2019 \\
\hline Silvicultural system & Clear-cuts \\
\hline Harvesting system & $\begin{array}{c}\text { Motor-manual tree felling \& } \\
\text { processing }+ \text { Forwarding }\end{array}$ \\
\hline
\end{tabular}

${ }^{a}$ Figures based on the provisions of contractual documents

${ }^{b}$ Terrain slope was 5 to more than $15 \%$ in the area of test

${ }^{c}$ Refers only to the time of the field test

$\Rightarrow$ the segment located between points 1 and 2 (hereafter S12) was a bladed skidding road having an approximate width of $4 \mathrm{~m}$, being characterized by a non-levelled condition, sharp turns and sharp changes in the longitudinal profile. Longitudinal terrain slope ranged from 10 to more than $40 \%$ and was non-evenly distributed on relatively short segments. The segment condition indicated a heavy traffic by skidding operations

$\Rightarrow$ the segment located between points 2 and 3 (hereafter S23) was a non-bladed skidding road running outside the forest, non-levelled, relatively straight, with many boulders surfacing the soil. Longitudinal slopes ranged from 10 to more than $20 \%$ and were evenly distributed on relatively long segments. It was trafficked by skidding operations and it was relatively compacted

$\Rightarrow$ the segment located between points 3 and 4 (hereafter S34) was a non-bladed skidding road running inside the forest, non-levelled, relatively straight, with boulders surfacing the soil and having a limited width. Longitudinal slopes ranged from 10 to more than $20 \%$ and were nonevenly distributed on relatively short segments. It was trafficked by skidding operations and it was relatively compacted

$\Rightarrow$ the segment located between points 4 and 5 (hereafter S45) was a natural soil, inside the

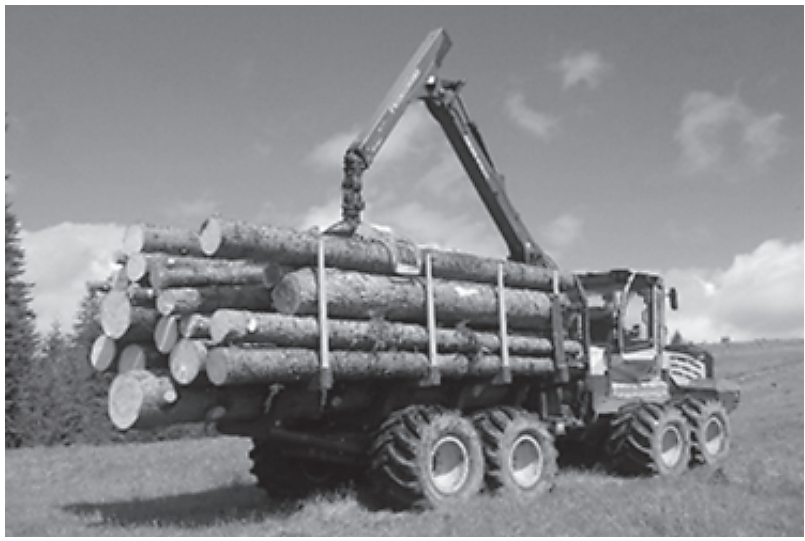

Fig. 2 Forwarder prototype tested in the field during the demonstration events from May 2019 with the courtesy of Forwarder2020 consortium

forest, non-levelled, with some boulders surfacing the soil and stumps present at the surface. Longitudinal slopes ranged from 5 to more than $15 \%$ and were non-evenly distributed on relatively short segments. In general, the compaction was less than on the rest of road segments

The tested machine was a HSM 208F 14t HVT-R2 forwarder prototype (Fig. 2) that was developed in the framework of Forwarder 2020 innovation project, based on the concept of $208 \mathrm{~F}$ series and integrating several innovations developed within the consortium such as the suspended cabin designed to improve the ergonomics, comfort and safety when operating at increased speed, a hybrid hydrostatic-mechanical power-split transmission (HVT-R2) designed to bridge some of the commonly known issues of the used transmissions such as those working solely on mechanical or hydrostatic concepts (HSM 2019), and an extended capacity of the bunk. The machine was equipped with a Volvo (Tier 4 8-1 in-line 6 cylinder) engine and a Palfinger Epsilon S110F crane. Prior to the field tests under the real operational conditions, the performance of the prototype machine was compared to that of the series machine equipped with a standard transmission by tests on the roller bench, and then by some comparative field tests carried out in Romania, whose results have not been published yet. The main conclusion of the roller bench tests was that a significant performance improvement may be achieved at higher speeds (Schmidt 2019), which also contributes to fuel savings as high as $1.36 \mathrm{l} / \mathrm{km}$ (HSM 2019). During the field tests, the machine was operated by a worker who had an extensive work experience on the $208 \mathrm{~F}$ series 
machine. He participated in the comparative supervised tests that were carried out using the same machine in May 2019, close to the location of this field test, and he was instructed to work by balancing his safety and comfort with the operation speed.

\subsection{Performance Assessment}

\subsubsection{General Concept}

The general concept used in the performance assessment was that of measuring, deriving and evaluating a set of key performance indicators in terms of both objective and subjective categories. The objective performance indicators were those generally described by the system engineering literature (Wasson 2006) and by the forestry operations concepts and terminology (Acuna et al. 2012, Björheden et al. 1995) such as the time and fuel consumption, operational speed, productivity and efficiency. Then, given the fact that driving at significantly increased speeds may affect the driver's perception of his/her own safety, in the subjective performance assessment, a face-to-face discussion approach was used to see if the driver felt comfortable to run the machine at different speeds and, on several occasions, a researcher joined the cab during the operations to personally evaluate such issues. The approach used was also market-oriented in the sense that the performance indicators selected for the evaluation were chosen to respond and clarify how and to what extent the innovative components integrated into the machine could satisfy, by their outputs in terms of performance, the preferences and operational needs of potential customers. For this, the work of Borz et al. (2019a) has served as both reference and guideline to first develop a set of indicators. As such, and given that many of these indicators are inter-related, for the purpose of this study, the following indicators were selected: the time consumption as a reference to build up figures on productivity and efficiency, fuel consumption and operational speed, with the later being related to both productivity and fuel consumption. The described approach was used to be able to show the differences, if any, compared to the existing results.

\subsubsection{Time Consumption}

The time consumption concept used in this study was agreed by the IUFRO (Björheden et al. 1995) and it was adapted to the main functions provided, in general, by the forwarders. The division of work on subsequent hierarchic levels was based on the recommendations of Spinelli et al. (2013), by limiting the number work elements (tasks) to those strictly needed to characterize the performance in terms of time consump- tion and operational speed and to account for the variability of these performance indicators given by the characteristics of delimited road segments. For reasons such as foreseeing that some of the work elements would develop at increased speeds, enabling a fast data collection, limiting the intrusion of observers in the way of doing work and being able to derive the operational speed as required by the study concept, the division of work place time into elemental time consumption categories was made in the office phase of the study based on the data collected via GPS and video recording. Similar techniques were previously documented and used with success in many fields, including those of forest engineering (Grigolato et al. 2016, Mologni et al. 2018). To this end, a customergrade Garmin ${ }^{\circledR}$ GPSMAP 64st handheld unit was placed on the machine cab to avoid signal obstruction, then it was reinforced by adhesive tape and set to collect locations at one second rate $(1 \mathrm{~Hz})$. In parallel, a mini video camera was placed inside the cab at a height that allowed a good field of view on the bunk and crane during the operation and set to continuously collect video files. Among the capabilities of the used devices, attention is drawn to the high accuracy of GPS device that in some open conditions may be as high as 1 to 5 meters; under mature canopy, the accuracy stays in between 4 to $12 \mathrm{~m}$ (Keefe et al. 2019). Another feature is the extended battery life of the used camera (typically more than 10 hours), which enables it to record, label and store consecutive date and time stamped video files having a duration of 20 minutes each. In addition, time and motion studies carried out using a GPS approach have been proven to save important research resources and to automate, to some extent, data processing, while their outputs are of a great importance in mapping the observed events (e.g. Borz et al. 2018, Talagai et al. 2018, Borz et al. 2019b) and in inferring other parameters such as the operational speed. As such, the GPS approach was accepted and used in many forest operations productivity studies (e.g. Borz et al. 2015, McDonald and Fulton 2005, Strandgard and Mitchell 2015). Moreover, the video recording approach is one of the limited options available to accurately document the tasks (e.g. Borz et al. 2014) and it is particularly useful when the researcher presence in the field is either not possible or not advisable. For such an approach, however, the processing effort at the office has been proved to be resource intensive in some cases, depending on the complexity of the studied system, and therefore on the number of work elements within a work cycle (Musat et al. 2016).

Back at the office, the two collected datasets were analyzed together to extract the elemental time 
consumption and to derive other relevant indicators. First of all, the files collected via GPS, using a sampling rate of $1 \mathrm{~Hz}$, were analyzed together in the framework of QGIS open source free software (version 2.14.0 Essen) after some refinements that aimed to exclude the locations characterizing non-work place time, since the forest road geometry was documented using the same device. Then, the field-recorded GPX files were converted into Microsoft ${ }^{\circledR}$ Excel ${ }^{\circledR}$ spreadsheets for further processing. Here, logical functions were used to convert strings into numbers or to extract numbers from strings where needed (e.g. speed data). Then, an initial database was built as a spreadsheet containing a set of parameters required for analysis such as the identification number, date and clock time, GPS speed and location. Video files were analyzed by playing them into the VLC media player open-source free software and a pen-and-paper approach was used to document the operations by coding the main tasks (Table 2) and by extracting the clock time for the beginning and ending breakpoints of each task.
Based on the codes noted on the paper and on the time-labels extracted at the break points, the initial database was further documented by adding the task (work element) codes for each 1-second observation, an approach that was enabled by the time attributes contained in the database.

\subsubsection{Operational Speed}

As one of the important goals of this study was to evaluate the improvements in terms of operational speed, the database developed for time consumption estimation was further documented to include the features related to this performance indicator. To do so, the skidding road was conceptually divided in segments according to the description provided above, and based on the geometry and locations collected by GPS. The database was further documented by including codes to describe the direction of movement and the bunk state in relation to speed for empty and loaded turns. The rest of the observed tasks were excluded from this analysis because there was less potential to show improvements in events such as, for instance,

Table 2 Description of work elements used in the study

\begin{tabular}{|c|c|c|}
\hline $\begin{array}{l}\text { Work and Time Consumption } \\
\text { Category } \\
\text { Scope of use and analysis }\end{array}$ & Abbreviation & Description and comments \\
\hline $\begin{array}{l}\text { Total Study Time } \\
\text { Study level }\end{array}$ & TST & Total time recorded in the field as workplace time and delays caused by the study itself \\
\hline $\begin{array}{l}\text { Delays Caused by Study } \\
\text { Study level }\end{array}$ & SD & $\begin{array}{l}\text { Delays caused by the need to refuel the machine after completion of each work cycle as well as those } \\
\text { caused by the need to make adjustments to the devices used to collect data }\end{array}$ \\
\hline $\begin{array}{l}\text { Work Place Time } \\
\text { Study level }\end{array}$ & WPT & $\begin{array}{l}\text { Total time observed and recorded in the field after the exclusion of delays caused by the study itself. } \\
\qquad \text { Used for characterization at the study level }\end{array}$ \\
\hline $\begin{array}{l}\text { Empty Turn Time } \\
\text { Study level, Cycle wise }\end{array}$ & ETT & $\begin{array}{l}\text { Time consumed when driving empty from the landing to the felling block. Repeated at work cycle level } \\
\qquad \text { and also used for characterization at the study level }\end{array}$ \\
\hline $\begin{array}{l}\text { Loading Time } \\
\text { Study level, Cycle wise }\end{array}$ & LT & $\begin{array}{l}\text { Time consumed when effectively loading and when moving to access the wood in the felling block or } \\
\text { along a skid road. Repeated at work cycle level and also used for characterization at the study level }\end{array}$ \\
\hline $\begin{array}{l}\text { Assisting Time } \\
\text { Study level, Cycle wise }\end{array}$ & AT & $\begin{array}{l}\text { Time consumed when assisting the fellers by the crane to buck the trees, as well as the time spent to } \\
\text { clear the ground using the crane and to make space for movement. Repeated only for few work cycles } \\
\text { and also used for characterization at the study level }\end{array}$ \\
\hline $\begin{array}{l}\text { Loaded Turn Time } \\
\text { Study level, Cycle wise }\end{array}$ & $\mathrm{LTT}$ & $\begin{array}{l}\text { Time consumed when driving loaded from the felling block to landing. Repeated at work cycle level and } \\
\qquad \text { also used for characterization at the study level }\end{array}$ \\
\hline $\begin{array}{l}\text { Unloading Time } \\
\text { Study level, Cycle wise }\end{array}$ & UT & $\begin{array}{l}\text { Time consumed to unload the logs at landing and to arrange them into the pile, including small } \\
\text { movements for doing so. Repeated at work cycle level and also used for characterization at the study level }\end{array}$ \\
\hline $\begin{array}{l}\text { Maneuvering Time } \\
\text { Study level, Cycle wise }\end{array}$ & MT & $\begin{array}{l}\text { Time consumed to turn back the machine from the wood pile to the refueling place at the landing. } \\
\text { Repeated at work cycle level and also used for characterization at the study level }\end{array}$ \\
\hline \begin{tabular}{|l|l|l} 
Delays \\
Study level \\
\end{tabular} & DT & $\begin{array}{l}\text { Time consumed for personal reasons or to wait in the felling block for the fellers to process trees. Used } \\
\qquad \text { for characterization at the study level }\end{array}$ \\
\hline \begin{tabular}{|l|} 
Productive (Delay Free) Time \\
Study level, Cycle wise
\end{tabular} & DFT & ys. Used for characterization at the study level \\
\hline
\end{tabular}


moving when loading. This is because the speed that could be reached in such events depends largely on the location of $\log$ bunches and the distance between them. As the log bunches were grouped at relatively small distances among them, the speed in these movements was expected to be that which can be sustained also by the machines produced in series. Operational speed, on the other hand, was assumed to be the GPS speed and, given this aspect, the expectation was that the real ground speed be higher. This approach was helpful in determining the speed that could be sustained in relation to the condition of skidding road, therefore, in the estimation of operational speed behavior that could occur in different scenarios related to the quantitative and qualitative features of the forwarding infrastructure. In addition to these categories of conditions, data on operational speed was further used to characterize the performance of operations at the study level by categorization and mapping.

\subsubsection{Fuel Consumption}

Fuel consumption was measured using the direct method (Ignea et al. 2017) of refilling to full (Acuna et al. 2012). This approach was used to be able to compute the unit fuel consumption and to relate, to some extent, the fuel consumption to some of the operational variables. An electric pump attached to a 4001 external tank (resolution of 0.01 l, Fig. 3) was used to refill the tank to full after placing the machine in a flat location on the forest road, near the landing, after the completion of each work cycle (Table 2). Before refilling the fuel tank and for each work cycle, the board computer was checked to see the inclination of the machine. In cases in which it exceeded 3\%, the machine was replaced to stay in that inclination limit.
During each refill, measures were undertaken to eliminate the air possibly stored in the tank and a fixed mark was used each time to fill the tank to the same level. Nevertheless, one could assume a reasonable 0.51 error per work cycle, a fact that would not significantly affect the results, given that the fuel consumption indicators derived in this study have used the total fuel consumption measured in the field tests. Visual periodic checks were also undertaken to see if the amount of the fuel used and measured corresponded to that missing from the tank.

\subsubsection{Operational Variables}

Only the most important operational variables were either measured or derived for this study. The distances covered during the empty turn (DET, m), loading (DL, $\mathrm{m}$ ) and loaded turn (DLT, $\mathrm{m}$ ) were measured in the QGIS software after joining the developed database to the files containing the geometry and location of GPS collected data. To correct these distance categories by slope and to estimate the real distance, a $10 \mathrm{~m}$ contour layer was constructed from the freely available imagery data under the QGIS web data repository and used to calculate the altitudinal differences needed to compute the slope. Distance covered by maneuvers at the landing was set to $20 \mathrm{~m}$ by a direct measurement. For a given work cycle, the operational distance $(\mathrm{DO}, \mathrm{m})$ was considered to be the sum of the above categories, while the average extraction distance (DA, m) was set conventionally by dividing DO by 2 . Given the approach used to document the data on distance, a resolution of $10 \mathrm{~m}$ was set to describe the operational distance data.

Production data was based on detailed measurements that were carried out, for each work cycle, at the
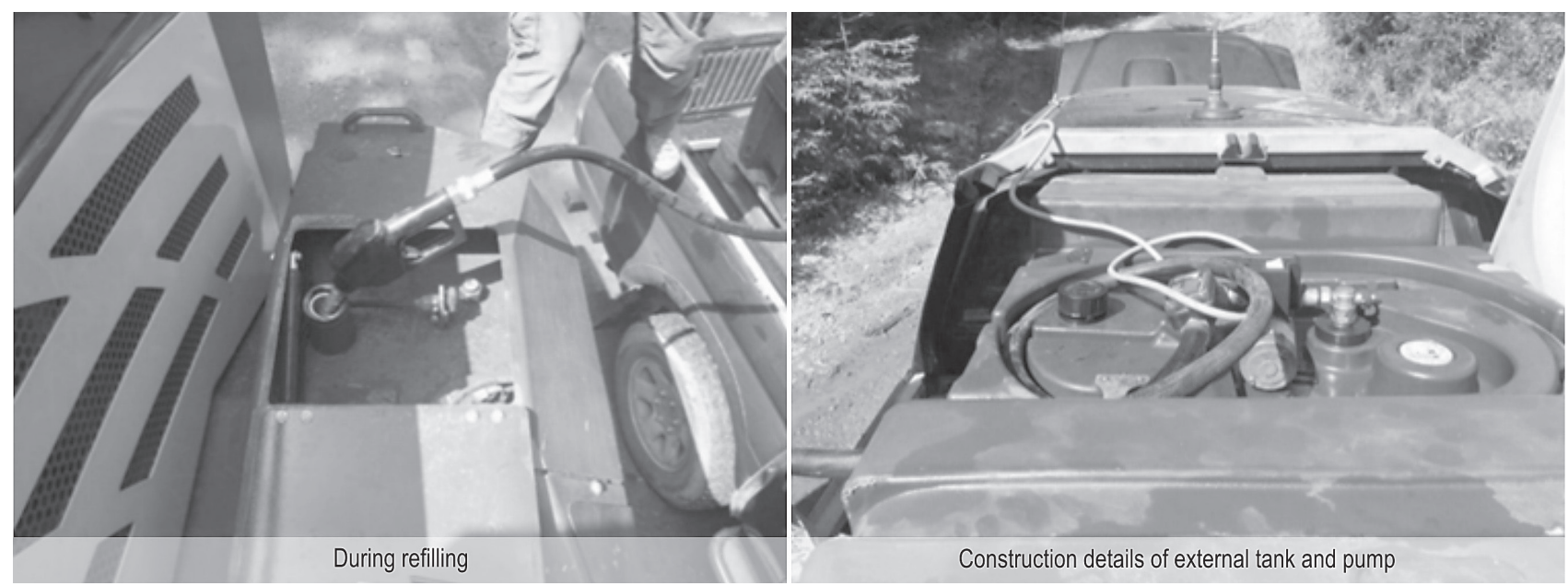

Fig. 3 Electric pump used to refill the tank 
landing. Volume of each $\log \left(\mathrm{m}^{3}\right.$ over bark, hereafter $\mathrm{m}^{3}$ o.b.) was estimated using the conventional approach, based on the diameters at the ends measured to the nearest centimeter and the length of each log measured by a tape to the nearest $5 \mathrm{~cm}$. Small parts of $\log$, buttress ends and other parts of smashed wood were visually estimated and, for each turn, a volume of $0.1 \mathrm{~m}^{3}$ o.b. was added to correct the production. A conversion factor of $0.85 \mathrm{t} / \mathrm{m}^{3}$ o.b., as for fresh coniferous wood in the area, was used to estimate the forwarded mass per turn, and at the study level. Unfortunately, there was no literature available in relation to the conversion factors of fresh wood in the area, but still, the used factor was considered to be more than realistic given the season of harvesting. This is because the area is characterized by a colder climate in which the growth patterns of Norway spruce are different compared to the rest of the country, a fact that contributes to the differentiation of a particular anatomic structure of the spruce wood (Dinulică et al. 2019). Primary field data, such as the diameters and lengths of the logs, including the corrections, was collected in the time that the machine was engaged in operations in the felling block and it was noted, for each turn, on a paper field book. Production estimates were obtained at the office after transferring the data into Microsoft ${ }^{\circledR}$ Excel $^{\circledR}$ sheets.

\subsection{Data Analysis}

Since the collected data set was limited in terms of number of work cycles, the data analysis was framed around descriptive statistics. While a modelling approach would have been very helpful in deducing more accurate functional relations between the input of resources and variation of operational variables, this approach was omitted due to the limited availability of the machine and the amount of resources needed to run an extensive modelling study, facts that constrained the data to a limited set. Nevertheless, the key performance indicators could be extracted by the approach of this study at a sufficient precision to be able to make comparisons and to emphasize the value added by innovative technology integrated into the prototype. Therefore, the following methods were used to analyze the data:

$\Rightarrow$ time consumption for tasks was structured as defined in the time concept used and both the absolute and relative values were computed as descriptive statistics

$\Rightarrow$ operational variables were computed and reported as descriptive statistics, then both the time consumption and those variables characterizing the production were used to estimate the relevant indicators of productive performance: gross and net productivity and efficiency rates

$\Rightarrow$ based on the statistics of operational variables and those characterizing the production, fuel consumption was reported using the main descriptive statistics. To this end, the concept of the study distinguished between three categories of unit fuel consumption (UFC), by reporting the inputs of fuel to the production expressed as volume and mass, respectively, by reporting the fuel consumption on an hourly basis. To enable other comparisons, part of the data was used to compute the unit fuel consumption as liters per kilometric ton $(1 / \mathrm{tkm})$, a metric that accounts for the mass moved over distance

$\Rightarrow$ a centerpiece of this study was that of evaluating if and to what extent the operational speed could be sustained at higher values compared to the existing machines. As the study site provided the conditions to evaluate such outcomes, the statistical approach used to evaluate the operational speed was that of deriving descriptive statistics in more detail that referred to both the study, in general, and to the typical skid road segments and bunk states in particular. Therefore, thematic mapping procedures were used with the support of QGIS to show the situation on operational speed in relation to the first two ranges of the transmission system $(\leq 4 \mathrm{~km} / \mathrm{h}$ and 5 to $18 \mathrm{~km} / \mathrm{h}$ ). Then, descriptive statistics were built and reported to characterize the empty and loaded turns at the study level and, finally, descriptive statistics were built and reported to show the differences in the operational speed sustained on different configurations of the skidding roads and bunk states

All the statistical work was carried out using the Microsoft ${ }^{\circledR}$ Excel $^{\circledR}$ software. Part of the derived data, however, was analyzed by the means provided by QGIS software.

\section{Results}

\subsection{Time Consumption, Operational Variables and Productivity}

Following data analysis, the total study time (TST) amounted to almost 20 hours, out of which the work place time accounted for $82 \%$. After the exclusion of delays, the delay free time (DFT) amounted to 15.5 hours representing $95 \%$ of the work place time (WPT). In the former category, loading time (LT) was domi- 
Table 3 Descriptive statistics of operational variables and production

\begin{tabular}{|c|c|c|c|c|c|}
\hline \multirow[b]{2}{*}{$\begin{array}{c}\text { Category and } \\
\text { Parameters } \\
\text { Abbreviation }\end{array}$} & \multicolumn{5}{|c|}{ Descriptive Statistics } \\
\hline & $\begin{array}{c}\text { No. of } \\
\text { observa- } \\
\text { tions }\end{array}$ & Sum & $\begin{array}{c}\text { Minimum } \\
\text { value }\end{array}$ & $\begin{array}{c}\text { Maximum } \\
\text { value }\end{array}$ & \begin{tabular}{|c} 
Mean \\
Standard \\
Deviation
\end{tabular} \\
\hline \multicolumn{6}{|c|}{ Distance } \\
\hline $\begin{array}{l}\text { Operational } \\
\text { Distance, m } \\
\text { D0 }\end{array}$ & 15 & 44150 & - & - & - \\
\hline $\begin{array}{l}\text { Empty Turn } \\
\text { Distance, m } \\
\text { DET }\end{array}$ & 15 & 21760 & 960 & 1660 & $\begin{array}{l}1451 \\
(277)\end{array}$ \\
\hline $\begin{array}{l}\text { Distance Covered } \\
\text { when Loading, m } \\
\text { DCL }\end{array}$ & 15 & 720 & 10 & 150 & $48(36)$ \\
\hline $\begin{array}{l}\text { Loaded Turn } \\
\text { Distance, m } \\
\text { DLT }\end{array}$ & 15 & 21370 & 720 & 1650 & $\begin{array}{l}1425 \\
(329)\end{array}$ \\
\hline $\begin{array}{l}\text { Distance Covered } \\
\text { in Landing } \\
\text { Maneuvers, m } \\
\text { DLM }\end{array}$ & 15 & 300 & - & - & 20 \\
\hline \multicolumn{6}{|c|}{ Production } \\
\hline $\begin{array}{l}\# \text { L Logs } \\
\mathrm{NL}\end{array}$ & 702 & 702 & 28 & 66 & $47(10)$ \\
\hline $\begin{array}{l}\text { Payload, } \mathrm{m}^{3} \text { o.b. } \\
\text { PL }\end{array}$ & 15 & 221.3 & 8.6 & 19.4 & $14.8(2.5$ \\
\hline $\begin{array}{l}\text { Production, } \\
\mathrm{m}^{3} \text { o.b. } \\
\mathrm{P}\end{array}$ & - & 221.3 & - & - & - \\
\hline $\begin{array}{l}\text { Production* }{ }^{*}, t \\
P^{*}\end{array}$ & - & 188.1 & - & - & - \\
\hline $\begin{array}{l}\text { Corrected } \\
\text { Production, } \mathrm{m}^{3} \text { o.b. } \\
\text { CP }\end{array}$ & - & 222.8 & - & - & - \\
\hline $\begin{array}{l}\text { Corrected } \\
\text { Production*, t } \\
\text { CP* }^{*}\end{array}$ & - & 189.4 & - & - & - \\
\hline
\end{tabular}

nant (about 41\%), being followed by empty (ETT) and loaded turns (LTT) that shared similar proportions (about $23.5 \%$ ) and by the unloading time (UT) that accounted for almost $10 \%$. However, the maneuvers between log bunches available in the forest were also included in the loading time. Maneuvering at landing (MT) and assisting into the felling block (AT) took less than $3 \%$ of the delay-free time.

The total distance covered by driving the forwarder prototype during the study (DO) was estimated at about $44 \mathrm{~km}$ (Table 3). Empty and loaded turns were deployed at relatively similar distances that accounted, on average, for about $1.4 \mathrm{~km}$, and the average distance covered when loading was of about $50 \mathrm{~m}$. Using the procedures described in the materials and methods section, the average extraction distance was estimated at about $1.5 \mathrm{~km}$. A rough estimation on the speed of operations, including here only those tasks that involved movement of the machine, would be of $3.14 \mathrm{~km} / \mathrm{h}$, a figure that, given the operational conditions, may characterize a first improvement. In terms of production, a total of 702 logs were forwarded during the study, excluding here the short pieces for which the volume was estimated visually. In these conditions, the production at study level $(\mathrm{P})$ was estimated at $221.3 \mathrm{~m}^{3}$ o.b. and corrected at $222.8 \mathrm{~m}^{3}$ o.b., standing for a total moved mass that was estimated at cca. 189 tons.

Based on the above figures, Table 4 shows the main indicators characterizing the productive performance. Under the assumption of no delays, productivity was rated at about $14.4 \mathrm{~m}^{3}$ o.b./hour. Under the conditions of a perfect work organization in tree felling and processing operations, therefore by excluding the time spent in assisting operations, this figure would have reached about $14.6 \mathrm{~m}^{3}$ o.b./hour, meaning that the contribution of a better work organization in this direction is expected to be rather small. Delays, on the other hand, affected the productivity rate by almost $5 \%$ $\left(\mathrm{P}_{\text {gross }}=13.713 \mathrm{~m}^{3}\right.$ o.b./hour). As the delays were mostly personal, a supplementary improvement may rest in a better management of the work time. The value of both gross and net efficiency rate was rather similar, while the gross value of the effect of delays is slightly higher.

Payload per turn (PL), on the other hand, varied widely between about 9 and $19 \mathrm{~m}^{3}$ o.b. Lower figures were related to a reduced availability, in some cases, of wood prepared as logs into the felling block, a fact that affected the productivity.

Table 4 Productivity and efficiency indicators

\begin{tabular}{|c|c|c|c|c|c|c|c|}
\hline Operational conditions & $\begin{array}{l}\text { DFT } \\
\text { hours }\end{array}$ & $\begin{array}{l}\text { WPT } \\
\text { hours }\end{array}$ & $\begin{array}{c}C P \\
m^{3} \text { o.b. }\end{array}$ & $\begin{array}{c}P_{\text {net }} \\
\mathrm{m}^{3} \text { o.b./h }\end{array}$ & $\begin{array}{c}P_{\text {gross }} \\
\mathrm{m}^{3} \text { o.b.h.h }\end{array}$ & $\begin{array}{c}E_{\text {net }} \\
h / \mathrm{m}^{3} \text { o.b. }\end{array}$ & $\begin{array}{c}\mathrm{E}_{\text {gross }} \\
\mathrm{h} / \mathrm{m}^{3} \text { o.b. }\end{array}$ \\
\hline $\begin{array}{l}\text { Average extraction distance, } \mathrm{DA}=1470 \mathrm{~m} \\
\text { Average operational distance, } \mathrm{DO} \mathrm{m}=2940 \mathrm{~m} \\
\text { Average payload, } \mathrm{PL}=14.75 \mathrm{~m}^{3} \text { o.b. } \\
\text { Average no. of logs per turn, } \mathrm{NL}=46.80\end{array}$ & 15.50 & 16.25 & 222.78 & 14.373 & 13.713 & 0.070 & 0.073 \\
\hline
\end{tabular}




\subsection{Operational Speed}

Fig. 4 shows an overview of operational speed at global level (Fig. 4a), as well as of the skidding road segments divided according to the concept of the study (S45 and S34 - Fig. 4b, S23 and S12 - Fig. 4c). For demonstration, two speed categories have been used, corresponding to the behavior of transmission system as described in the material and methods section. As shown, the dominant operational speed was that of more than $5 \mathrm{~km} / \mathrm{h}$ that corresponds to the second, power-split range of the transmission, in which the machine behaves very well in terms of efficiency and fuel savings in off-road conditions.

The main goal of improvement was to be able to drive at higher speeds during the empty and loaded turns, which could result in increased productivity and significant fuel savings. In this regard, at study level, both median and mean values of empty and loaded turn speeds were quite similar. In fact, the median values computed based on the locations categorized as empty and loaded turns were $6 \mathrm{~km} / \mathrm{h}$. Average values for the same data were 5.9 and $5.8 \mathrm{~km} / \mathrm{h}$ for the loaded and empty turns, respectively.

However, the data varied quite largely in relation to the skidding road condition. Fig. 5 shows the descriptive statistics of operational speed as a breakdown on the type of task and bunk state. On the S45 skidding road segment the average speed was about $3.8 \mathrm{~km} / \mathrm{h}$. Then, for the S34 road segment, the opera-

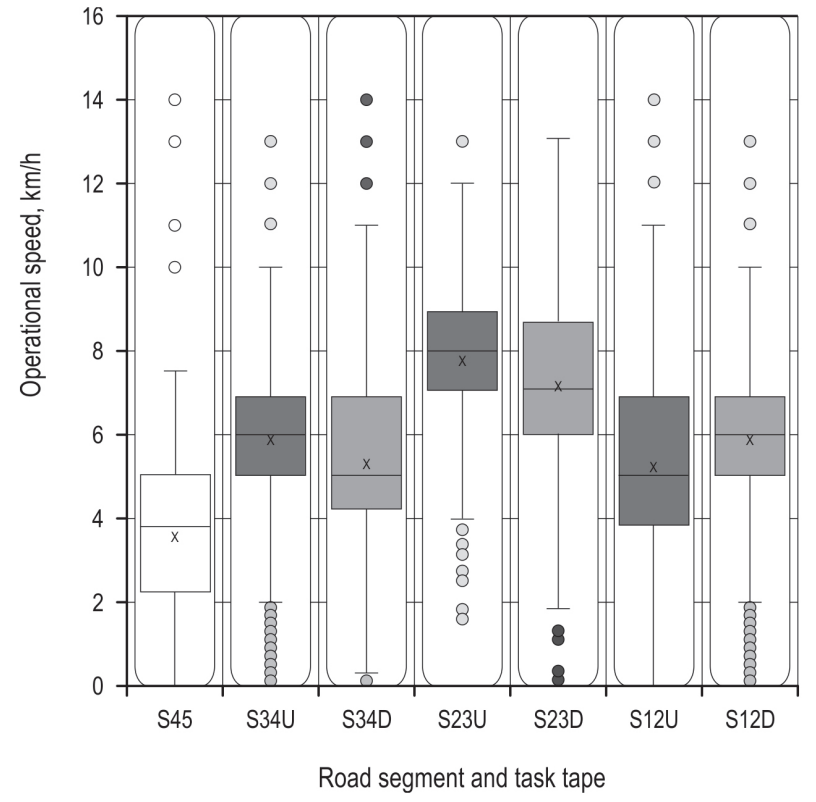

Fig. 5 Descriptive statistics of operational speed for uphill (unloaded, U) and downhill (loaded, D) turns on delimited skidding road segments (S)

tional speed when driving unloaded in the uphill direction was about $5.9 \mathrm{~km} / \mathrm{h}$, being somehow higher than that of downhill uploaded driving (about $5.5 \mathrm{~km} / \mathrm{h}$ ). The highest average operational speed was that of a relatively straight road segment (S23). It was about

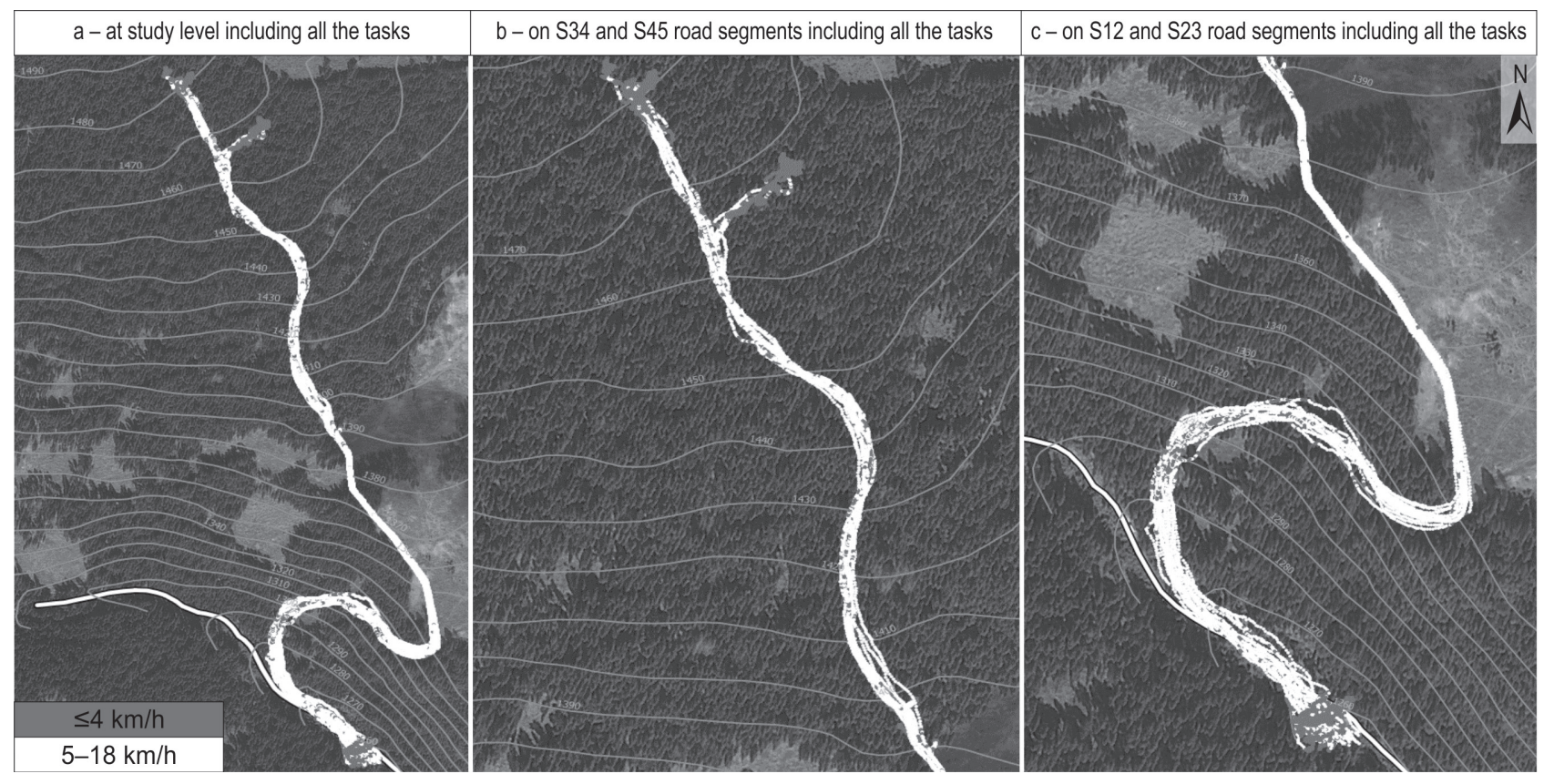

Fig. 4 Map of operational speed 


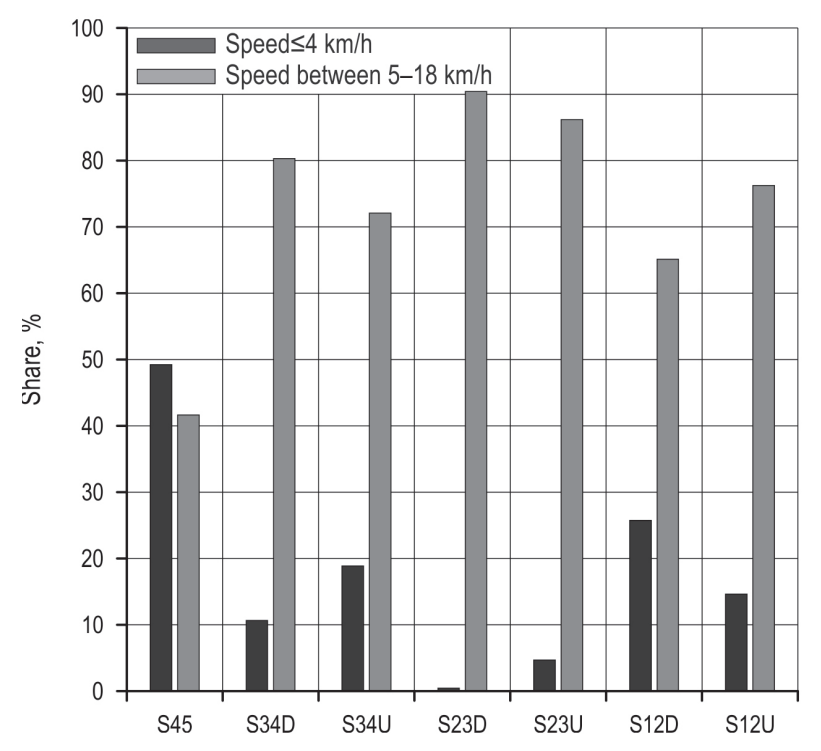

Fig. 6 Share of locations collected via GPS on operational speed categories, tasks and bunk states

$7.7 \mathrm{~km} / \mathrm{h}$ when driving unloaded in the uphill direction (S23U) and about $7.1 \mathrm{~km} / \mathrm{h}$ when driving uploaded in the downhill direction (S23D). For S12, the average operational speed was about $5.3 \mathrm{~km} / \mathrm{h}$ when driving uphill (S12U) and about $5.8 \mathrm{~km} / \mathrm{h}$ when driving downhill (S12D). Speeds higher than $4 \mathrm{~km} / \mathrm{h}$ were sustained as shown in Fig. 6. For S45, such speeds were only sustained in about $46 \%$ of cases, but here a differentiation in terms of bunk state and driving direction was not feasible given the ground conditions. Significant improvements were found, however, for the rest of roads segments, with the best results for S23, a case in which a speed higher than $4 \mathrm{~km} / \mathrm{h}$ was sustained for more than $90 \%$ of the analyzed observations. For speeds sustained in the range of $10-18 \mathrm{~km} / \mathrm{h}$ (not shown herein), the best results were found for S23U (12.6\% of cases) and S23D (14.3\% of cases).

Based on the above results, one could say that the prototype behaved very well as it was able to sustain high operational speeds. However, to be able to clearly differentiate the performance gains compared to conventional machines, comparative studies should be implemented in the future to evaluate the effectiveness of both machine types working under similar conditions. The forwarder driver was asked periodically how he felt about the speed of operation and a researcher joined the cab to see for himself how the speed may affect the comfort and safety of operation. Indeed, the forwarder driver responded that if the conditions for all the road had been as those on the S23 road segment, he would have probably been able to drive even faster. Also, he stated that in the condition of the forest and limited space, the driving during the tests was close to the best he could manage (S34 and S45). This was also the case of the S12, where the road was characterized by sharp turns and very steep segments for which he stated that he had to control the speed when driving loaded in the downhill direction.

\subsection{Fuel Consumption}

Fuel consumption estimates, as they resulted from the field measurements and data analysis, are given in Table 5. There was an evident relation between the fuel consumption per turn and the operational distance but a model has not been developed given the small set of data used. The hourly rate was estimated based on all the time spent with engine working and all the fuel consumed during the tests, and it was about 17.1 1 .

Based on the production statistics and the average operational conditions, the unit fuel consumption was estimated at cca. $1.25 \mathrm{l} / \mathrm{m}^{3}$ o.b. Assuming the conversion factor used to estimate the moved mass, the unit fuel consumption was also estimated at cca. 1.51/t. This figure was translated in a unit fuel consumption of $0.4991 / \mathrm{tkm}$.

\section{Discussion}

In relation to productivity and efficiency, the results of this study have shown promising figures although it is quite difficult to make comparisons with other studies. This is because the reported results are affected by many factors, which are further affected by their variability. For instance, a known factor that affects the productivity is the availability of wood to

Table 5 Fuel Consumption Indicators

\begin{tabular}{|c|c|c|c|c|c|c|c|}
\hline Operational conditions & $\begin{array}{c}\mathrm{FC} \\
\mathrm{L}\end{array}$ & $\begin{array}{l}\text { WPT } \\
\text { hours }\end{array}$ & $\begin{array}{c}C P \\
\mathrm{~m}^{3} \text { o.b. }\end{array}$ & $\begin{array}{c}C P^{*} \\
\mathrm{t}\end{array}$ & $\begin{array}{l}\text { UFC } \\
\text { I/h }\end{array}$ & $\begin{array}{c}\text { UFC } \\
\text { l/m } \mathrm{m}^{3} \text { o.b. }\end{array}$ & $\begin{array}{c}\text { UFC } \\
1 / t\end{array}$ \\
\hline $\begin{array}{l}\text { Average extraction distance, } \mathrm{DA}=1470 \mathrm{~m} \\
\text { Average operational distance, } \mathrm{DO}=2940 \mathrm{~m} \\
\text { Average payload, } \mathrm{PL}=14.75 \mathrm{~m}^{3} \text { o.b. } \\
\text { Average no. of logs per turn, } \mathrm{NL}=46.80\end{array}$ & 277.87 & 16.25 & 222.78 & 189.4 & 17.104 & 1.247 & 1.467 \\
\hline
\end{tabular}


be loaded per turn, which is dependent on the tree size and extraction intensity (Oprea 2008). Acknowledging the wide availability of studies reporting on forwarding performance, this part of discussion was built by referring to some studies that shared at least one common characteristic in terms of operational variables or technology used. For instance, a recent study of Proto et al. (2018) has indicated productivities in the range of 15 to $25 \mathrm{~m}^{3} / \mathrm{h}$, but these referred to extraction distances, which were half of those reported in this study. Accounting for the case study developed in Calabria (Italy), the same authors have indicated a productivity of cca. $15 \mathrm{~m}^{3} / \mathrm{h}$ for a JD1110E machine, having a capacity of $12 \mathrm{t}$, that operated in selective cuts on a slope of $25 \%$, which is comparable, to some extent, to that from this study, and for the conditions of an average extraction distance of about $700 \mathrm{~m}$. As some of the features they described are comparable with those of this study, it could be inferred that a similar productivity was obtained for almost a double distance in this study. Nevertheless, it cannot be assumed that the difference in performance is purely the effect of distance since this study reports on clear cuts and the study of Proto et al. (2018) reports on selective cuts. In fact, their payload per turn was $10 \mathrm{~m}^{3}$, indicating probably a lower availability of wood even if the average tree size was similar. In another case study, Proto et al. (2017) have found productivities of 14.4 and $15.7 \mathrm{~m}^{3} / \mathrm{h}$ for extraction distances of approximately 300 and $600 \mathrm{~m}$, respectively, for two John Deere machines (1110D and 1010D) operating on slopes of 26 and $29 \%$, respectively. A rough comparison would emphasize the differences found, at least in terms of distance, which was much lower compared to this study as, in their study, the forwarded wood was bunched to the secondary roads (i.e. forwarding roads). Nevertheless, the payloads were much lower and the type of extraction was selective in their study. Similar findings apply when comparing to other international studies. For instance, in the study by Tiernan et al. (2004), clear felling was carried out on roughly half of the extraction distance and indicated a similar productivity, while Pandur et al. (2018) found a productivity of approximately $18 \mathrm{~m}^{3} / \mathrm{h}$ on flat lands, but in their study the log size was higher and the extraction distance was less (about $1.1 \mathrm{~km}$ ). For steep terrain and an extraction distance of $0.8 \mathrm{~km}$, Dinev et al. (2015) found productivities of 44-53 $\mathrm{m}^{3} /$ day (probably $5-6 \mathrm{~m}^{3} / \mathrm{h}$ assuming a work shift of 8 hours). Also, for an extraction distance of $1.1 \mathrm{~km}$, a payload of $12-13 \mathrm{~m}^{3}$ and clear-cut conditions, Slamka and Radocha (2010) found a productivity of cca. $11 \mathrm{~m}^{3} / \mathrm{h}$ on gentle to moderate slopes. Therefore, it could be stated that the tested prototype improves the operations in terms of productivity as this figure was higher compared to the existing data, which spans, however, better extraction conditions, at least in terms of distance.

For both, empty and loaded turns, the average running speed in the field test was close to $6 \mathrm{~km} / \mathrm{h}$, under the argument that it refers to quite variable conditions of sampling, standing also for the GPS speed, which is known to be less than the real ground speed. Some examples coming from the literature indicate similar speeds that were only sustained for the empty turns and, in some cases, only for flat lands (Proto et al. 2017, Proto et al. 2018). For relatively similar conditions in terms of machine used, slope and payload, however, Slamka and Radocha (2010) found speeds of 2.5 and $4.0 \mathrm{~km} / \mathrm{h}$ for the loaded and empty turns, speeds that were sustained and were higher even on natural soil as reported by this study. In fact, there are many studies that were developed in various conditions, showing the limits reached for empty and loaded turns in terms of speed. For empty turn, the reported speeds were in the range of $1.6-5 \mathrm{~km} / \mathrm{h}$, while for the loaded turn these were much lower, in the range of $2.2-3.7 \mathrm{~km} / \mathrm{h}$ (Dinev et al. 2015, Ghaffaryian et al. 2007, Manner et al. 2016, Pandur et al. 2018, Stankić et al. 2012, Williams et al. 2016). From this point of view, both the cabin and the transmission system of the tested prototype worked synergistically and very well. On the one hand, the cabin provided the comfort and safety for the operator, which was also proven by the presence of the researcher in the cab. Based on this feature, the transmission system was enabled to work in the second, power-split range, that enabled a faster driving. These capabilities are particularly emphasized by the part of the skidding road that corresponded to the typical roads designed for forwarding, where the sustained speeds were, on average, close to $8 \mathrm{~km} / \mathrm{h}$. Under the assumption of providing well-maintained and levelled roads, speeds of $10 \mathrm{~km} / \mathrm{h}$ or even higher could be sustained both during empty and loaded travel. This capability was tested (results not shown herein) during some supervised tests carried out in May 2019, aimed also to compare the performance of the prototype with that of a conventional machine made by the same producer. However, in conditions in which the skid roads are very steep, unmaintained and having sharp turns, operational speeds equal if not even higher, compared to those reported by the existing literature, can still be expected. This also applies to forest skidding roads, characterized by a limited width space. Nevertheless, it was impossible to measure other effects that could affect the ground speed such as slipping; therefore, the GPS speed was used as a reference to evaluate the performance in this aspect, 
and in order to improve the reliability of data, the study was conducted for several days and speed data coming from the same skidding road segments were averaged. As an overestimation of distance measured by GPS can be expected when sampling at high frequencies (Ranacher et al. 2016), the real ground speed would be in fact underestimated by the GPS speed.

Fuel consumption can also be compared, normally, for similar conditions. However, this is often quite difficult to make because one needs to be able to control many factors. For instance, Holzleitner et al. (2011) have shown that the hourly fuel consumption in forwarders may reach a wide variation depending purely on their engine output. While their mean hourly fuel consumption was $11 \mathrm{l}$, the data variation range was wider than $18 \mathrm{l} / \mathrm{h}$ and, even for the same engine output, it reached, in some cases, more than $12 \mathrm{l} / \mathrm{h}$. This pinpoints the fact that other operational factors have an important effect on the fuel consumption given the fact that, for the same operational condition, it has been shown that there are no significant differences in fuel consumption in empty and loaded turns (Cosola et al. 2016). To this end, following the field test, the average extraction distance was estimated to be close to $1.5 \mathrm{~km}$, while the average moving distance was close to $2.9 \mathrm{~km}$. At the same time, the average payload per turn was close to $15 \mathrm{~m}^{3}$. This resulted in an estimated fuel consumption of $17.1 \mathrm{l} / \mathrm{h}, 1.25 \mathrm{l} / \mathrm{m}^{3}$ and 1.47 1/t. The study of Pandur et al. (2018) indicates, for similar conditions in terms of payload and log size, but for an extraction distance of $1.1 \mathrm{~km}$, a fuel consumption of $15.6 \mathrm{l} / \mathrm{h}, 1.18 \mathrm{l} / \mathrm{m}^{3}$ and $1.29 \mathrm{l} / \mathrm{t}$ reported for flat terrains. Similar figures were found by Danilovic et al. (2015) in flat terrain, reaching as much as $1.41 / \mathrm{m}^{3}$. Also, for flat terrains, Pandur et al. (2018) reported a fuel consumption of $0.56 \mathrm{l} / \mathrm{tkm}$. This last figure can be used as a reference for comparison as it reflects the effort as mass over distance and may emphasize the difference brought by innovative technology. In this regard, and by considering all the travelled distance irrespective of the bunk state $(2.9 \mathrm{~km})$, the unit fuel consumption reported by this study was estimated at about $0.501 /$ kilometric tone. Since both the measurements of fuel consumption and production could be affected by errors, it makes sense to analyze some worse case scenarios. Assuming, even if highly unreasonable to think so, and error or $10 \%$ in the fuel consumption measurement (i.e. adding 301 more) and a deviation of $10 \%$ in the estimated volume (i.e. excluding $20 \mathrm{~m}^{3}$ ), which is also highly unreasonable, the unit fuel consumption would be cca. $1.5 \mathrm{l} / \mathrm{m}^{3}$ and cca. $0.62 \mathrm{l} / \mathrm{tkm}$, the last figure being close to that reported by Pandur et al. (2018) for flat terrains and much lower distances. Also, under the assumption of a conversion factor from $\mathrm{m}^{3}$ o.b. to tons of 0.8 , the above reported figures would be $1.56 \mathrm{l} / \mathrm{t}$ and $0.54 \mathrm{l} / \mathrm{tkm}$, respectively. However, even this last scenario is highly unrealistic since the forwarded wood was fresh.

\section{Conclusions}

Results of this study bring evidence on the performance improvement by the modular innovation approach as a measure to increase the effectiveness of forwarding operations. In particular, for excessively long extraction distances, a synergic integration of the suspended cabin with an innovative transmission system enabled a faster and safer operation of the machine with improved effects in the productivity and fuel economy. As such, the machine was able to operate in the most efficient range of the transmission, which not only enabled driving at higher speeds but also contributed to a significant fuel economy. As the speed is known to affect the productivity and therefore also the cost of operations and since the fuel intake in forwarding is a crucial aspect for sustainability in terms of both cost and environmental impact, it can be concluded that the prototype tested has a lot of proven potential to ensure the sustainability of operations in low access forests. Also, without any exaggeration, in case of better road conditions, the machine could be characterized by an even higher, unleashed potential to positively contribute to the key performance indicators discussed above. In turn, this can contribute to less costs involved by the development of transportation infrastructure as well as to enabling forwarder users to invest in new technology based on an improved expected return in terms of cost effectiveness.

\section{Acknowledgments}

This study was supported by the Forwarder2020 project-Smart Forwarder for sustainable and efficient forest operation and management - financed by the European Union under the Horizon 2020-BB-20162017 call on Bio-based innovation for sustainable goods and services - Supporting the development of a European Bioeconomy - Topic BB-04-2016, Innovation Action, proposal number 727883 (https://www. forwarder2020-project.eu/). The authors acknowledge the support of the aforementioned organization. Also, the authors would like to thank the Forwarder2020 consortium for their support as well as Mr. Eng. Cristian Dobrean, Eng. Marius Cheța and Eng. Nicolae Talagai, for involvement, help and logistic support provided for this study. 


\section{References}

Acuna, M., Bigot, M., Guerra, S., Hartsough, B., Kanzian, C., Kärhä, K., Lindroos, O., Magagnotti, N., Roux, S., Spinelli, R., Talbot, B., Tolosana, E., Zormaier, F., 2012: Good practice guidelines for biomass production studies. CNR IVALSA Sesto Fiorentino (National Research Council of Italy - Trees and Timber Institute): Sesto Fiorentino, Italy, 1-51 p.

Apafaian, A.I., Proto, A.R., Borz, S.A., 2017: Performance of a mid-sized harvester-forwarder system in integrated harvesting of sawmill, pulpwood and firewood. Ann. For. Res. 60(2): 227-241. https://doi.org/10.15287/afr.2017.909

Björheden, R., Apel, K., Shiba, M., Thompson, M., 1995: IUFRO Forest work study nomenclature. Swedish University of Agricultural Sciences, Department of Operational Efficiency: Grappenberg, Sweden, 1-16 p.

Borz, S.A., Rommel, D., Ziesak, M., Vasiliauskas, G., 2019a: Operational requirements and preferences towards forwarding technology. Bulletin of the Transilvania University of Braşov - Series II: Forestry - Wood industry - Agricultural Food Engineering 12(61)1: 1-12. https://doi.org/10.31926/ but.fwiafe.2019.12.61.1.1

Borz, S.A., Talagai, N., Cheța, M., Chiriloiu, D., Gavilanes Montoya, A.V., Castillo Vizuete, D.D., Marcu, M.V., 2019b: Physical strain, exposure to noise and postural assessment in motor-manual felling of willow short rotation coppice: Results of a preliminary study. Croat. J. For. Eng. 40(2): 377-387. https://doi.org/10.5552/crojfe.2019.550

Borz, S.A., Talagai, N., Cheța, M., Gavilanes Montoya, A.V., Castillo Vizuete, D.D., 2018: Automating data collection in motor-manual time and motion studies implemented in willow short rotation coppice. Bioresources 13(2): 3236-3249. https://doi.org/10.15376/biores.13.2.3236-3249

Borz, S.A., Ignea, G., Popa, B., Sparchez, G., Iordache E., 2015: Estimating time consumption and productivity of roundwood skidding in group shelterwood system - a case study in a broad leaved mixed stand located in reduced accessibility conditions. Croat. J. For. Eng. 36(1): 137-146.

Borz, S.A., Bîrda, M., Ignea, G., Popa, B., Câmpu, V.R., Iordache, E., Derczeni, R.A., 2014: Efficiency of a Woody 60 processor attached to a Mounty 4100 tower yarder when processing coniferous timber from thinning operations. Ann. For. Res. 57(2): 333-345. https://doi.org/10.15287/ afr.2014.258

Cosola, G., Grigolato, S., Ackerman, P., Monterotti, S., Cavalli, R., 2016: Carbon footprint of forest operations under different management regimes. Croat. J. For. Eng. 37(1): 201-217.

Dinulică, F., Albu, C.T., Vasilescu, M.M., Stanciu, M.D., 2019: Bark features for identifying resonance spruce standing timber. Forests 10(9): 799. https://doi.org/10.3390/f10090799

Dinev, D., Vardunski, J., Nacheva-Georgieva, P., 2015: Logging and transportation by John Deere 1110D forwarder in Bulgaria - productivity and impact on the soil. In: Proceed- ings of the $48^{\text {th }}$ Formec Symposium, Linz, Austria, 4-8 October.

Forwarder2020: Available online: https://www.forwarder2020-project.eu/ (accessed 15 October 2019)

Garmin Romania: Available online: https://www.garmin. com/ro-RO/software/basecamp/ (accessed 25 September 2019)

Ghaffaryian, M.R., Stampfer, K., Sessions, J., 2007: Forwarding productivity in Southern Austria. Croat. J. For. Eng. 28(2): 169-175.

Grigolato, S., Panizza, S., Pellegrini, M., Ackerman, P., Cavalli, R., 2016: Light-lift helicopter logging operations in the Italian Alps: a preliminary study based on GNSS and video camera system. Forest Science and Technology 12(2): 88-97. https://doi.org/10.1080/21580103.2015.1075436

Heinimann, H.R., 2007: Forest operations engineering and management - the ways behind and ahead of a scientific discipline. Croat. J. For. Eng. 28(1): 107-121.

Holzleitner, F., Stampfer, K., Visser, R., 2011: Utilization rates and cost factors in timber harvesting based on longterm machine data. Croat. J. For. Eng. 32(2): 501-508.

HSM, 2019: Product of the year - HSM 208F 14t HVT-R2, Forest Romania 2019, Zizin, Brasov, $5^{\text {th }}$ of September, presented by Felix zu Hohenlohe.

Ignea, G., Ghaffaryian, M.R., Borz, S.A., 2017: Impact of operational factors on fossil energy inputs in motor-manual tree felling and processing: results of two case studies. Ann. For. Res. 60(1): 161-172. https://doi.org/10.15287/afr.2016.705

ISO, 2009: Machinery for forestry - Mobile and self-propelled machinery - Terms, definitions and classification (ISO 6814:2009). Machinery. 1-7.

Keefe, R.F., Wempe, A.M., Becker, R.M., Zimbelman, E.G., Nagler, E.S., Gilbert, S.L., Caudill, C.C., 2019: Positioning methods and the use of location and activity data in forests. Forests 10(5): 458. https://doi.org/10.3390/f10050458

Lindroos, O., La Hera, P., Häggström, C., 2017: Drivers of advances in mechanized timber harvesting - a selective review of technological innovation. Croat. J. For. Eng. 38(2): 243-258.

Manner, J., Norfjell, T., Lindroos, O., 2016: Automatic load level follow-up of forwarders' fuel and time consumption. International Journal of Forest Engineering 27(3): 151-160. https://doi.org/10.1080/14942119.2016.1231484

Marchi, E., Chung, W., Visser, R., Abbas, D., Nordfjell, T., Mederski, P.S., McEwan, A., Brink, M., Laschi, A., 2018: Sustainable forest operations (SFO): A new paradigm in a changing world and climate. Sci. Total Environ. 634: 13851397. https://doi.org/10.1016/j.scitotenv.2018.04.084

Mologni, O., Dyson, P., Amishev, D., Proto, A.R., Zimbalatti, G., Cavalli, R., Grigolato, S., 2018: Tensile force monitoring on large winch-assist forwarders operating in Brithis Columbia. Croat. J. For. Eng. 39(2): 193-204. 
McDonald, T.P., Fulton, J.P., 2005: Automated time study of skidders using global positioning system data. Comput. Electron. Agric. 48(1): 19-37. https://doi.org/10.1016/j.compag.2005.01.004

Moskalik, T., Borz, S.A., Dvorak, J., Ferencik, M., Glushkov, S., Muiste, P., Lazdins, A., Styranivsky, O., 2017: Timber Harvesting Methods in Eastern European Countries: A Review. Croat. J. For. Eng. 38(2): 231-241.

Musat, E.C., Apafaian, A.I., Ignea, G., Ciobanu, V.D., Iordache, E., Derczeni, R.A., Spârchez, G., Vasilescu, M.M., Borz, S.A., 2016: Time expenditure in computer aided time studies implemented for highly mechanized forest equipment. Ann. For. Res. 59(1): 129-144. https://doi.org/10.15287/ afr.2015.473

Oprea, I., 2008: Tehnologia exploatării lemnului (Timber harvesting technology); Transilvania University Press: Braşov, Braşov, Romania. 97-100 p.

Pandur, Z., Šušnjar, M., Bačić, M., Lepoglavec, K., Nevečerel, H., Đuka, A., 2018: Fuel consumption of forwarders in lowland forests of pedunculate oak. South-east Eur for 9(1): 73-80. https://doi.org/10.15177/seefor.18-07

Pandur, Z., Vusić, D., Papa, I., 2009: Dodatna oprema za povećanke proizvodnosti forvardera. Nova mehanizacija šumarstva 30(1): 19-25.

Poje, A., Grigolato, S., Potočnik, I., 2019: Operator exposure to noise and whole-body vibration in a fully mechanised CTL forest harvesting system in karst terrain. Croat. J. For. Eng. 40(1): 139-150.

Proto, A.R., Macri, G., Visser, R., Harrill, H., Russo, D., Zimbalatti, G., 2018: Factors affecting forwarder productivity. Eur. J. For. Res. 137: 143-151. https://doi.org/10.1007/s10342017-1088-6

Proto, A.R., Macri, G., Visser, R., Harril, H., Russo, D., Zimbalatti, G., 2017: A case study on the productivity of forwarder extraction in small-scale Southern Italian forests. Small-Scale For. 17: 71-87. https://doi.org/10.1007/s11842017-9376-z

Qgis project. Available online: https://www.qgis.org/en/site/ (accessed 15 September 2019)

Ranacher, P., Brunauer, R., Trutschnig, W., Van der Spek, S., Reich, S., 2016: Why GPS makes distances bigger than they are. Int. J. Geogr. Inf. Sci. 30(2): 316-333, http://dx.doi.org/1 0.1080/13658816.2015.1086924

Stankić, I., Poršinsky, T., Tomašić, Ž., Tonković, I., Frntić, M., 2012: Productivity models for operational planning of timber forwarding in Croatia. Croat. J. For. Eng. 33(1): 61-78.
Schmidt, V., 2019: Effizienzbetrachtung von Fahrantrieben bei Rückezügen (Efficiency analysis of travel drives on return trains). B.Sc. Thesis, Karlsruher Institut für Technologie, Karlsruhe.

Spinelli, R., Laina-Relaño, R., Magagnotti, N., Tolosana, E., 2013: Determining observer and methods effects on the accuracy of elemental time studies in forest operations. Balt. For. 19(2): 301-306.

Strandgard, M., Mitchell, R., 2015: Autoated time study of forwarders using GPS and a vibration sensor. Croat. J. For. Eng. 36(2): 175-184.

Slamka, M., Radocha, M., 2010: Results of harvesters and forwarders operations in Slovakian forests. Forestry Journal 56(1): 1-15. https://doi.org/10.2478/v110114-009-0010-7

Talagai, N., Cheța, M., Gavilanes Montoya, A.V., Castillo Vizuete, D.D., Borz S.A., 2018: Predicting time consumption of chipping tasks in a willow short rotation coppice from Global Positioning System and acceleration data. In Proceedings of the Biennial International Symposium Forest and Sustainable Development, Brașov, Romania, $25^{\text {th }}-27^{\text {th }}$ of October, Transilvania University Press: Brasov, Romania, 1-12.

Tiernan, D., Zeleke, G., Owende, P.M.O., Kanali, C.L., Lyons, J., Ward, S.M., 2004: Effect of working conditions on forwarder productivity in cut-to-length timber harvesting on sensitive forest sites in Ireland. Biosyst. Eng. 87(2): 166-177. doi: 10.1016/j.biosystemseng.2003.11.009

Visser, R., Spinelli, R., 2012: Determining the shape of the productivity function for mechanized felling and fellingprocessing. J. of For. Res-Jpn. 17(5): 397-402. https://doi. org/10.1007/s10310-011-0313-2

VLC Media Player. Available online: https://www.videolan. org/vlc/index.ro.html (accessed 15 September 2019)

Vusić, D., Šušnjar, M., Marchi, E., Spina, R., Zečić, Z., Picchio, R., 2013: Skidding operations in thinning and shelterwood cut of mixed stands - Work productivity, energy inputs and emissions. Ecol. Eng. 61(part A): 216-223. http://dx.doi. org/10.1016/j.ecoleng.2013.09.052

Wasson, C.S., 2006: System analysis, design, and development. Concepts, principles and practices; John Wiley \& Sons Inc.: Hoboken, New Jersey, USA; 17-38.

Williams, C., Ackerman, P., 2016: Cost-productivity analysis of South African pine sawtimber mechanized cut-to-length harvesting. South. Forests 78(4): 267-264. https://doi.org/10. 2989/20702620.2016.1183096

(C) 2021 by the authors. Submitted for possible open access publication under the terms and conditions of the Creative Commons Attribution (CC BY) license (http://creativecommons.org/licenses/by/4.0/). 
Authors' address:

Prof. Stelian Alexandru Borz, PhD * e-mail: stelian.borz@unitbv.ro Assoc. prof. Marina Viorela Marcu, PhD e-mail: viorela.marcu@unitbv.ro Transilvania University of Brasov Faculty of Silviculture and Forest Engineering Department of Forest Engineering Forest Management Planning and Terrestrial Measurements

Sirul Beethoven 1

500123, Brasov

ROMANIA

Maria Francesca Cataldo, MSc e-mail: maria.cataldo@unirc.it Mediterranean University of Reggio Calabria Department of AGRARIA Feo di Vito IT89122 Reggio Calabria ITALY

${ }^{*}$ Corresponding author 